ments, which are brown. Each spot with a light brown hair. The cervical shield same color as the body; lateral edges brown; underside same as above ; thoracic feet tipped with brown. Length, .24 mm. Foodplant, asters; drawing together several leaves so as to form a bunch. May 3 I. Imago emerged June 18 th.

Salebria celtella, Hulst (MS.)

Head pitchy black, with irregular, dirty, whitish markings, and an oblique stripe of the same color on each side. Body pale green, with a number of pea green, equidistant, longitudinal stripes, as broad as the intervening spaces. Cervical shield jet black, and on which the stripes of the body are sordid white. Along the subdorsum is a row of minute piliferous spots, and two rows along the sides. Body beneath green, and without marking, except the first segment is jet black, as are also the first pair of thoracic feet. A few hairs are also scattered over the body, Length, .22 mm. Food plant, Celtis occidentalis, folding together a few of the terminal leaves. Aug. Spins a rude cocoon between leaves.

\title{
NOTE ON THE GENUS CROCOTA AND PROF. J. B. SMITH.
} BY A. R. GROTE.

Readers of Mr. Smith's papers will have noticed the frequent critical remarks at my expense, and it may have appeared to them that I have been often most culpable. But, in every case, although I have not the pleasure of knowing all of Mr. Smith's publications, these criticisms can be shown to be perversions of the case. So in the genus Crocota, in which determinations are difficult, Mr. Smith says (p. I93, vol. XXI.):"The matter has been further confused by Mr. Grote's persistent refusal to refer to Mr. Reakirt's species," and further that "he ignores them altogether." I ask anyone how I can "confuse" the "matter" by simply not referring to Mr. Reakirt's species by name, seeing that I do not know these species, have never seen the types, and am not disposed to believe in them? And, moreover, since Mr. Reakirt's descriptions refer to Eastern species, postdating my own, and those of other author's which I discuss, if they are not distinct species they are thus clearly synonyms, and Mr. Smith says the descriptions may be "poor," as indeed they seem to me to be. But the whole statement is inaccurate, for everywhere, 
where I have referred collectively to the species of Crocota, I have also expressly referred to Mr. Reakirt's descriptions, giving my reasons for not particularly citing the species by name. Hence, my writings have had the exactly contrary effect, to that stated by Mr. Smith, "of causing others to lose track of" Mr. Reakirt's "descriptions." I always reminded students of the existence of Mr. Reakirt's descriptions, though I confessed I could not make them out. Nor is Mr. Smiti apparently any wiser than I. I did, indeed, suppose that nigricans was a synonym of opella, or founded on the dark form of that species, but I kept this and all other surmises to myself, because I had no certain data to go upon, and a scientific writer must, in such cases, have a reasonable certainty. With regard to lecta, I, in my first list, am the first to refer treatii here, to show that I had probably rediscovered a totally unknown species since Boisduval's figure. I first, in fact, direct attention to this unrecognized figure, which has been copied in Encyc. Brit. To me belongs the credit of directing Mr. Smith's attention to this figure of leeta and its probable identity with treatii in my first Check List. This identification is not quite assured in the absence of any description; hence, in my new Check List, I made a query. If $\mathrm{Mr}$. Smith had written correctly and impartially on the genus Crocota he should have said: Mr. Grote first refers this genus to the Arctiince on account of the presence of ocelli, and removes it from the Lithosinnce where he leaves Ameria. Further, Mr. Grote has figured the species he described in Proc. Ent. Soc., and no doubt exists, in a confusing genus, of the species he intended. Instead of this, with the evident intention of making an adverse criticism coute qui coute, we have the perversions above exposed. As was the case when Mr. Smith replied to my statement, that, in the Deltoidince, the eyes were always " naked," that in one genus the eyes were "lashed" (as if these characters were contradictory or exclusive), it must seem clear that the limit of proper criticism is exceeded by Mr. Smith. The errors of an author must be judged by the material at his command in specimens and literature. If under all the circumstances under which he laboured his work is of a character virtually to advance the study of his subject, and if a large proportion of his determinations are accurate and in the state of the science very opportune, no right-minded person should be able to bring himself to prevert such labours. I may remark, in conclusion, that I do not regard Cydosia, Cerathosia or Gnophcela, as Arctiince, and I believe 
that they are thus incongruously placed and associated. Both Cydosia and Gnophcela appear to me to be Zygcenidce with Bombycid analogies in sensu Packard. I hope Dr. Packard may be induced to study these forms: Neither do I believe our Texan species of Cydosia to be the nobilitella of Cramer. But all these questions, which ever way a full knowledge of these moths my determine us, must be entered into without temper and without unnecessary animadversions upon those whose experience has led them to opposite conclusions from those reached by the final verdict, a verdict which Mr. Smith's studies will, we may hope,
be of a character to influence.

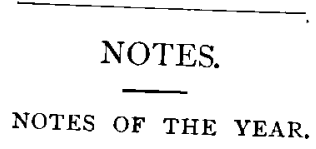

Dear Sir: With few exceptions insects were unusually scarce last season, probably on account of the continued cool weather and heavy rains. Colias Philodice, generally so abundant, was almost entirely absent, a few appeared in midsummer and the fall brood was more plentiful, but by no means abundant, and the latter might be said of most of our diurnals. The Noctuas were also conspicuous by their absence, at least at sugar, the baits failing to attract even the commonest species. Eufitchia ribearea was observed in numbers in a plot of black currant bushes, in an was abundant on shade trees about Royal Park, and Orgyia leucostigma species of Eristalis common on solidago bity. In the fall I found several Brousi being especially abundant, whilo blossoms, E. Bastardi and $E$. $E$. dimidiatus were less common while E. transversus, E. Tenax and presented, making it one of the worst collecting seasons in my experience.
. The other orders were poorly re-

F. B. Caulfield, Montreal.

\section{ACKNOWLEDGMENT.}

Dear Sir: The photograph from which the beautiful figure on p. 204, vol. xxi. of Papilio Turnus (aberrant form) was taken by Mr. H. N. was made direct by the new Isochromatic process, and the engraving have appeared in the article photograph. This acknowledgment should

J. Fletcher. 